\title{
Long term effects of treated wastewater irrigation on calcisol fertility: A case study of Sfax-Tunisia
}

\author{
Nebil Belaid ${ }^{1,2^{\star}}$, Catherine $\mathrm{Neel}^{2,3}$, Monem Kallel $^{4}$, Tarek Ayoub $^{5}$, Abdelmoneim Ayadi $^{1}$, \\ Michel Baudu ${ }^{2}$ \\ ${ }^{1}$ National School of Engineers of Sfax, Radio Analyzes and Environment laboratory (LRAE), Sfax, Tunisia; \\ ${ }^{*}$ Corresponding Author: belaidnebil@yahoo.fr \\ ${ }^{2}$ University of Limoges, Research Group, Water, Soil and Environment (GRESE), Limoges, France \\ ${ }^{3}$ CETE Lyon-DLCF, Clermont-Ferrand, France \\ ${ }^{4}$ National School of Engineers of Sfax, Water, Energy and Environment Laboratory (L.3E), Sfax, Tunisia \\ ${ }^{5}$ CRDA-Sfax, Sfax, Tunisia
}

Received 25 April 2012; revised 28 May 2012; accepted 16 June 2012

\section{ABSTRACT}

The use of treated wastewater (TW) for irrigation is increasingly being considered as a technical solution to minimize soil degradation and to restore nutrient content of soils. Indeed, TW usually contain large amounts of nutrient elements. The objective of this study is to evaluate the impact of long-term irrigation by TW on soil fertility under real field conditions. In the vicinity of the city of Sfax, a semi-arid region, a calcisol field has been irrigated for more $\mathbf{1 5}$ years with organic sodic TW; soil was modeled at three different depths $(0-30,30-60$ and $60-90 \mathrm{~cm})$ and along soil pits in the TW irrigated zone and in a nearby non-irrigated zone (control). Several parameters have been measured: Soils $\mathrm{pH}, \mathrm{CEC}$, exchangeable cations, nitrate and ammonia, total contents of nitrogen, phosphorus and other essential macro and micro nutrients, electrical conductivity, soil organic carbon and dissolved organic carbon. C/N ratio and SUVA were calculated for each soil layer. The calculation of the isovolumic mass balance on soil profile scale was used to measure macro and micro nutrients supply. The TW irrigation has led to important supply in organic carbon $(+100 \%)$, phosphorus $(+80 \%)$ and in most essential nutrients $(\mathrm{N}, \mathrm{Mn}$, $\mathrm{Zn})$. Due to the high rate of irrigation and low CEC of the studied soil, the added nutrient cations and nitrate are removed with leaching waters compared to the non-irrigated control soil. Moreover, Sfax's TW bring about important amounts of salts and $\mathrm{Na}$. Therefore the beneficial addition of nutrients could quickly be inhibited by the excessive supply of salts and available nitrogen. Apart from future crops produc- tion risk, groundwater degradation quality and soil fertility will be endangered over the long term.

Keywords: Arid Region; Wastewater; Irrigation; Fertility; El Hajeb-Sfax

\section{INTRODUCTION}

In arid and semi-arid regions of countries such as Tunisia which are facing rising serious water shortage problems, the reuse of urban wastewater for non potable purposes, such as agriculture [1-3] has became an usual practice. Indeed, wastewater reuse for irrigation has been the largest field of application because it usually offers some attractive environmental and socio-economic benefits, mainly due to the reduction of effluent disposal in receiving water bodies, to the supply of nutrients as fertilizers, and to the improvements in crops production during the dry season $[4,5]$. Benefits apart, planners are aware of the potential disadvantages of wastewater reuse for irrigation which are, aside from pathogenic contamination of irrigated crops, mainly related to the specific chemical composition of wastewater being somewhat different from most natural waters used in irrigation [6]. Over time, wastewater irrigation affects some soil parameters. Increase in soil $\mathrm{pH}$ is observed in acidic soils $[7,8]$, whereas slight decrease of $\mathrm{pH}$ is mentioned for alkaline soils [5,8-11]. In alkaline calcarous soils, the sligh acidification is due to the leaching of limestone by the leaching water [10]. Wastewater can also supply ammonia anion to soil which is another source of soil acidification [11]. In general, the decrease of $\mathrm{pH}$ is also explained by the low $\mathrm{C} / \mathrm{N}$ ratio of effluents and the subsequent enhancement of the organic mineralization substances $[7,10]$. Wastewater irrigation thus usually 
leads to macro and micro nutrients supply [5,11] which stimulates the microbial activity $[12,13]$ and promotes the mineralization of the soil organic matter. This can lead to the decrease of the soil cation exchange capacity $[7,10]$ and mitigate the soil buffer capacity. By the same way, wastewater usually contains elevated concentrations in metal elements such as $\mathrm{Mn}, \mathrm{Cu}$ and $\mathrm{Zn}$ which constitute essential micro nutrients for plants. Over time, the same elements can accumulate in the organic topsoil layer in such manner that they reach their critical level for plant growth.

Hence, the use of wastewater for irrigation of crops requires assessment of the balance in supply of macro and micro nutrient over the long-term. Most of previous mentioned studies recorded impacts on contents in macro and micro nutrients without any regard for changes in the total store of these elements in soil. Moreover, specific studies dedicated to highlight long-term impacts (along several decades) have involved soils that have been irrigated by untreated domestic effluents or municipal wastewaters (Rattan et al. [8]: 10 and $20 \mathrm{yr}$; Yadav et al. [5]: $30 \mathrm{yr}$; Solis et al. [10]: 50 and $100 \mathrm{yr}$ ). Thus, the treatment of wastewater has been generalized after the heighties on the spur of the F.A.O. guidelines for application in agriculture [4]. The treatment of urban effluents modifies their nutritional value, it is thus of great concern to assess whether the irrigation with treated wastewater (TW) still improves the soil quality or it could cause degradation to its fertility over the long term.

The objectives of this study are to evaluate the changes in soil fertility and to balance its essential elements in response to 15 -year-long treated wastewater irrigation (TW) within the city of Sfax (the second largest city in Tunisia). In this arid region, there are many signs of extremely low groundwater levels which were registered over the last three decades due to the increasing number of wells especially used for irrigation of crops [14]. Treated wastewater in Sfax has thus been used for irrigation since 1989. From that period, the irrigation perimeter has regularly been expanded as to reach the area of 600 ha. New extension of the area irrigated by wastewater is planned for twice over its present surface. This study is a part of a research program which aims at evaluating the impact of wastewater application on both soil and crops properties in the arid region of Sfax. The overall goals are to aid management of crop irrigation by wastewater, to reduce overexploitation of the local groundwater resources and to improve the water recharge of groundwater. Belaid et al. [15] have evidenced negative impact on the soil salinity and sodicity, especially in the northern part of the irrigation perimeter covered by a deep permeable fluvisol. Therefore, soil salinization and sodification are mitigated by the amount of exchangeable calcium in irrigated calcisol fields [15]. The present study thus focuses on this type of calcareous soils, which is mostly found in the Southern part of the irrigation perimeter.

\section{MATERIALS AND METHODS}

\subsection{Study Area}

The study area is settled at ten kilometres in the West next to the sewage treatment plant (Figure 1) near to the town of Sfax (approximately with one million of habitants) in crop fields, which are currently irrigated with treated wastewater whose plant receives domestic as well as industrial effluents from mainly canning factories and textile production. The region has an arid climate with monthly air temperature ranging from $11.3^{\circ} \mathrm{C}$ to $26.7^{\circ} \mathrm{C}$, dry summer and annual rainfalls of $200 \mathrm{~mm}$ mostly occurring from October to December. The average annual potential evaporation of $1200 \mathrm{~mm}$, combined with the low rainfall and high temperatures makes irrigation essential for crop production.

The present survey has been carried out in the area of the irrigation perimeter that is covered by a calcisol (according to the FAO World Reference Base for soil resources [16]). This soil presents an isohumic character and shows a homogeneous sandy to sandy loam texture.

As shown in Table 1, the selected area produces alternate cycles of crops, in association with permanent harvesting of olives, with successive winter and summer harvest of annual crops (oat, sorghum) sectioned every 10 years by a 3 -year-long cropping of alfalfa. This kind of cropping system requires irrigation by open surface furrows distributed every $24 \mathrm{~m}$ in-between each row of olive trees. The soil has been submitted to wastewater irrigation for 15 years. In order to assess the effects of the wastewater, a nearby field is taken as a control area which produces only olives and has been preserved from any source of irrigation (Figure 1).

\subsection{Samples of Preparation and Chemical Analyses}

Treated wastewater were sampled at the outlet of the Sfax wastewater treatment plant at different times and conserved at $4^{\circ} \mathrm{C}$ before characterization. Effluent samples were analyzed for $\mathrm{pH}$ and electrical conductivity $(\mathrm{ECw})$ using a $\mathrm{pH}$ meter (AFNOR standard method $\mathrm{N}^{\circ}$ NF T 90-008 [17]) and a conductimeter (AFNOR $\mathrm{N}^{\circ} \mathrm{NF}$ EN 27888 [17]) respectively. Chemical oxygen demand (COD), suspended solids (SS), biochemical oxygen demand (BOD) and total phosphorus were measured according to standard methods (AFNOR $\mathrm{N}^{\circ} \mathrm{NF} \mathrm{T}$ 90-018, NF EN 872, NF T 90-103, NF EN 1189 [17]). Cations and anions were measured using chromatography while 


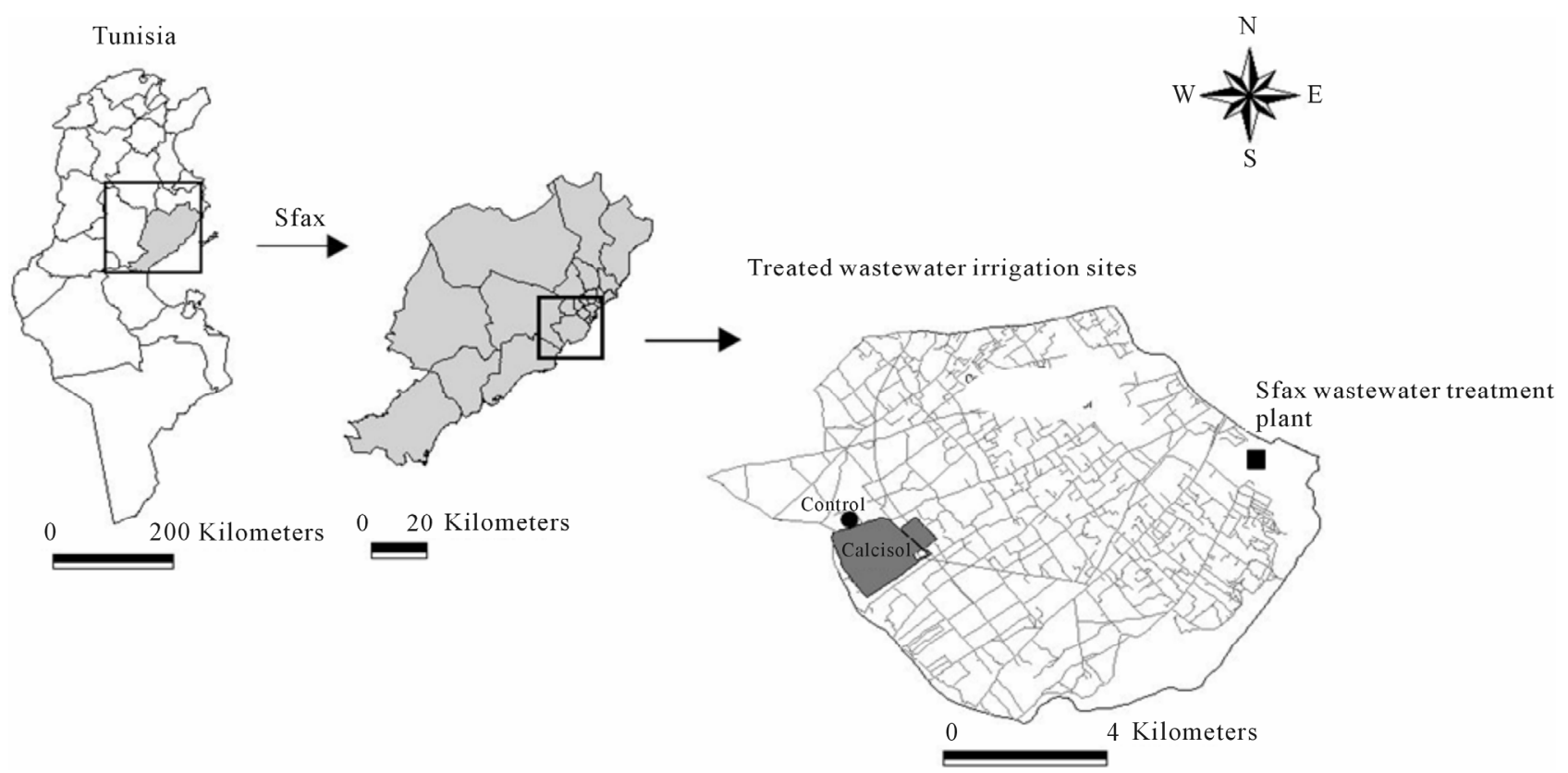

Figure 1. Map of studied area with location of the Sfax water treatment plant and of the calcisol site (TW irrigation perimeter in grey and point for the control site).

Table 1. Main characteristics of the studied calcisol site.

\begin{tabular}{|c|c|c|}
\hline Soil taxonomy & \multicolumn{2}{|c|}{ Light texture isohumic calcimagnesic soil according to the Tunisian pedological map } \\
\hline Soil depth & \multicolumn{2}{|c|}{$\begin{array}{l}\text { Moderately deep soil laid over a limestone crust approximately } 60 \mathrm{~cm} \text { deep } \\
\text { (the crust was dismantled in large part of the irrigated area) }\end{array}$} \\
\hline Soil texture & \multicolumn{2}{|c|}{ Sandy to sandy-loam with calcareous nodules in subsurface } \\
\hline Soil bulk density (surface layer) & \multicolumn{2}{|l|}{$1.4 \mathrm{~g} / \mathrm{cm}^{3}$} \\
\hline \multirow[t]{2}{*}{ Total $\mathrm{CaCO}_{3}$} & \multicolumn{2}{|l|}{$5 \%$ to $35 \%$} \\
\hline & Irrigated area & Control area (not irrigated) \\
\hline Cultural system & Associated cultivars (olives trees and forages crops) & Only olives trees \\
\hline Crop rotation & Winter (oat. ray grass) summer (sorghum) annual (alfalfa) & - \\
\hline Field area & 270 hectares including 90 hectares used for summer crops. & 1.5 hectares \\
\hline TW irrigation rate & $1000 \mathrm{~mm} / \mathrm{yr}$ & - \\
\hline Irrigation system & Surface irrigation by furrows & - \\
\hline Irrigation duration & 15 years & - \\
\hline Number of cores sampled & 7 & 1 \\
\hline
\end{tabular}

carbonates and bicarbonates were estimated by titration with $\mathrm{HCl}$ of an aliquot of the effluent samples (AFNOR $\mathrm{N}^{\circ}$ NF EN ISO 9963-2 [17]).

Soil sampling was performed in October 2006 after the harvest of summer crops and before the seeding of winter crops. Two soil sampling survey have been carried out. The first one concerned each horizon of soil that has been identified along pedological profiles drilled in the control area and in the irrigated field whereas the second sampling was done on plots covered by summer crops only by $30 \mathrm{~cm}$ thick soil layers using an Edelman-type auger. In order to account for spatial variations of soil texture and depth, 7 replications were performed in the irrigated field (IWC1 to IWC7). The control area was too small to allow such replications (NIC). Only 2 soil layers down to the depth of $60 \mathrm{~cm}$ were sampled in the control field as well as in the replication site IWC5 because of the occurrence of a concrete calcareous crust at depth of $60 \mathrm{~cm}$. This crust of sedimentary origin is irregular and has been generally dismantled in the irrigated field in 
order to help infiltration of irrigation waters, except in the control area, which has never been irrigated.

After air-drying, the soil samples were sieved at $2 \mathrm{~mm}$. Soil $\mathrm{pHw}$ and $\mathrm{pHKCl}$ were measured in a 2.5 soil to water $/ \mathrm{KCl} 1 \mathrm{M}$ slurry using a glass electrode. Saturation paste extracts of soils were prepared to determine the electrical conductivity of the soil samples (ECs). Soil samples CEC and contents in exchangeable cations were determined at actual soil $\mathrm{pH}$ by the cobaltihexamine method [18]. In calcareous soils, Belaid et al., [15] evidenced that the cobaltihexamine method provided more accurate values than the more usual method using $1 \mathrm{M}$ $\mathrm{NH}_{4}$ acetate solution [19] because of lesser dissolution of carbonates. Concentrations in $\mathrm{Ca}$ and $\mathrm{Mg}$ were performed by Atomic Absorption Spectrometry (AAS) while $\mathrm{Na}$ and $\mathrm{K}$ concentrations were determined by Flame Atom Emission Spectrometry (FAES).

$\mathrm{NO}_{3}$ and $\mathrm{NH}_{4}$ concentrations were measured in water soluble extracts using ionic chromatography (DIONEX DX-120) after water extraction using 1:5 soil to water ratio for $2 \mathrm{~h}$. Total nitrogen was determined by steam distillation after acid digestion using the Kjeldal procedure. Soil organic carbon (SOC) was determined by the Walkley and Black dichromate oxidation method. Water soluble organic $\mathrm{C}$, which is further referred to as dissolved organic carbon in this paper (DOC), was extracted with deionized water using a 2:1 (water to soil) ratio by shaking at fixed temperature during 3 hours [20]. The extracts were filtered using $0.22 \mathrm{~mm}$ filters and DOC concentration was measured using UV-persulfate oxidation on a TOC analyzer (TEKMAR DOHRMANN Phoenix 8000). UV absorption at $254 \mathrm{~nm}$ was measured using a Varian CARY 50 Probe UV-visible spectrophotometer. DOC quality; in terms of aromaticity of organic compounds, was determined as specific ultra violet absorbance (SUVA) which was calculated by dividing the absorbance at $254 \mathrm{~nm}$ by the DOC.

\subsection{Statistical Analysis}

One-sample T-test was used for comparing mean values obtained from replicates of measurements at an irrigated site to the values measured at the corresponding non irrigated control one. All measured values correspond to the average composite samples. However, due to the limited area of the control sites, and since the sampling was limited to the central part of them in order to avoid any influence of the neighbouring irrigation then in the absence of sampling replicate in the control area, no variance can be associated with the control values.

Hence, we have assumed that the values of the control site represent exact means to be compared with the variance of the mean values $(\mathrm{N}=7)$ measured at the corresponding irrigated site. Variance is expected to be larger in the irrigated zone than in the corresponding control one, so that the following sample T-tests can be considered as conservative:

$T=$ mean of TWE irrigated replicated values-control value standard deviation of TWE irrigated replicated values

A unilateral T-test was used to calculate the parameters, which are clearly increased or decreased after the irrigation by the treated wastewater (ECs, Exchangeable cations, $\mathrm{NO}_{3}$ and $\mathrm{NH}_{4}$ ). Whereas the bilateral T-test was chosen to identify parameters presenting no obvious response to the irrigation ( $\mathrm{pH}, \mathrm{CEC}, \mathrm{SOC})$. The global risk increases with the number of simultaneous tests performed. Therefore, we have also adopted a more severe individual rule than the usual one to minimize the increase of the global risk; the differences are considered significant when $p<1 \%$ instead of $p<5 \%$. In case of $p$ ranging between $1 \%<p<5 \%$, we conclude that the differences have to be confirmed. The T-tests were performed using SYSTAT Software version 12 http://www.systat.com/Store.aspx.

\section{RESULTS}

\subsection{Treated Wastewater Characteristics}

During the wastewater survey, the applied treated wastewater (TW) was always remained alkaline with an average basic $\mathrm{pH}$ value of 7.7 (Table 2). It also always presented a high level of total dissolved solids (TDS) of $3.7 \mathrm{~g} \cdot \mathrm{L}^{-1}$ and of suspended matter (SS). The level of biochemical oxygen demand (BOD) and chemical oxygen demand (COD) are ranged respectively between 37 and $220 \mathrm{mg} \cdot \mathrm{L}^{-1}$ and 123 and $700 \mathrm{mg} \cdot \mathrm{L}^{-1}$. The mean electrical conductivity (EC) of effluents reaches $5.7 \mathrm{mS} / \mathrm{cm}$. The sodium absorption ratio (SARw) of the treated wastewater ranges between 9.7 and 15.6. Theses parameters are higher than the usual ranges reported for other Tunisian TW [20] of similar mixed origins (industrial and domestic) than those of the Sfax TW. The Sfax' TW also contains great amounts of nitrate, phosphate and potassium which are crucial nutrients for plant growth and soil fertility.

\subsection{TW Irrigation Impacts on the Soil Proprieties}

In all sampling points in the irrigated field (Table 3) and in the two soil profiles, the $\mathrm{pH}\left(\mathrm{pH}_{\mathrm{w}}\right.$ and $\left.\mathrm{pH}_{\mathrm{KCl}}\right)$ of the soil water extracts remains alkaline at all depths (Table 4). There are no significant differences in soil $\mathrm{pHw}$ between the wastewater irrigated calcisol and the control calcisol.

By the same way, there are no significant differences in the contents of exchangeable $\mathrm{Ca}^{2+}$ between the irri- 
Table 2. Mean values of chemical properties of the treated wastewate (TW) generated by the wastewater treatment plant of Sfax from 1984 to 2007.

\begin{tabular}{|c|c|c|c|c|c|c|c|}
\hline \multirow{3}{*}{ Parameter } & \multirow{2}{*}{\multicolumn{2}{|c|}{ TW of Sfax }} & \multirow{3}{*}{$\begin{array}{l}\text { Tunisian } \\
\text { Standards }\end{array}$} & \multicolumn{4}{|c|}{ Examples of wastewater used for irrigation } \\
\hline & & & & \multicolumn{2}{|c|}{ Treated } & \multicolumn{2}{|r|}{ Untreated } \\
\hline & Mean & Ranges & & $\begin{array}{c}\text { Sousse, } \\
\text { Tunisia }^{a}\end{array}$ & $\begin{array}{c}\text { Sardinia, } \\
\text { Italia }^{\mathrm{b}}\end{array}$ & $\begin{array}{l}\text { Ramtha, } \\
\text { Jordan }^{\mathrm{c}}\end{array}$ & $\begin{array}{c}\text { Kurukshetra, } \\
\text { India }^{d}\end{array}$ \\
\hline pH & 7.7 & $7.1-8.7$ & $6.5-8.5$ & 7.8 & 7.73 & 7.3 & 7.4 \\
\hline ECw mS $\cdot \mathrm{cm}^{-1}$ & 5.7 & $4-7.7$ & 7 & 3.5 & 1.14 & - & 1.74 \\
\hline TDS $\mathbf{g} \cdot \mathbf{L}^{-1}$ & 3.7 & $3.56-5.13$ & - & - & - & 0.95 & 0.9 \\
\hline $\mathrm{SS} \mathbf{m g} \cdot \mathrm{L}^{-1}$ & 204 & $29-275$ & 30 & 32.7 & 46 & - & \\
\hline COD mg $\cdot \mathrm{L}^{-1}$ & 350 & $123-700$ & 90 & 88 & 34 & - & 382 \\
\hline BOD $_{5} \mathbf{m g} \cdot \mathbf{L}^{-1}$ & 107 & $37-220$ & 30 & 18.5 & - & - & 169 \\
\hline Pt $\mathbf{m g} \cdot \mathrm{L}^{-1}$ & 7.5 & $2.9-12.5$ & - & - & 1.64 & 15.5 & - \\
\hline $\mathrm{NO}_{3}^{-} \quad \mathrm{mg} \cdot \mathbf{L}^{-1}$ & 21 & $0.35-50$ & - & - & 1.63 & 29 & - \\
\hline $\mathrm{Cl}^{-} \mathbf{m g} \cdot \mathrm{L}^{-1}$ & 1662 & $903-2580$ & 2000 & 688 & 134 & - & - \\
\hline $\mathbf{S O}_{4}^{2-} \quad \mathbf{m g} \cdot \mathbf{L}^{-1}$ & 1022 & $508-1950$ & - & - & 121 & - & - \\
\hline $\mathrm{HCO}_{3}^{-} \mathrm{mg} \cdot \mathrm{L}^{-1}$ & 630 & $490-732$ & - & - & - & - & - \\
\hline $\mathrm{Na}^{+} \mathbf{m g} \cdot \mathbf{L}^{-1}$ & 1137 & $780-2100$ & - & 112 & 103 & - & - \\
\hline $\mathbf{K}^{+} \mathbf{m g} \cdot \mathbf{L}^{-1}$ & 57 & $17-105$ & - & 333 & 18 & 33.3 & - \\
\hline $\mathbf{M g}^{2+} \mathbf{m g} \cdot \mathbf{L}^{-1}$ & 151 & $129-209$ & - & 166 & 20 & - & - \\
\hline $\mathrm{Ca}^{2+} \mathrm{mg} \cdot \mathbf{L}^{-1}$ & 296 & $103-521$ & - & 258 & 53 & - & - \\
\hline $\mathrm{NH}_{4}^{+} \mathbf{m g} \cdot \mathrm{L}^{-1}$ & 67 & $61-73$ & - & - & 33 & - & - \\
\hline SAR & 12.4 & $9.7-15.6$ & - & 7.7 & 3 & 4.6 & - \\
\hline
\end{tabular}

Mean minimum and maximum values of samples characterised since 1984. ECw: Electric conductivity; TDS: Total dissolved solids; SS: Suspended matter; COD: Chemical oxygen demand; BOD: Biochemical oxygen demand; Pt: Total phosphorus; SAR: Sodium absorption ratio: ${ }^{\mathrm{a}} \mathrm{Klays}$ et al., $2010 ;{ }^{\mathrm{b}} \mathrm{Cappola}$ et al., 2004; ${ }^{\mathrm{c}}$ Rusan et al., 2007; ${ }^{\mathrm{d}}$ Yadav et al., 2002.

gated calcisol and the non-irrigated control calcisol (Table 3). This confirms the natural inorganic origin of this element that certainly reflects the presence of Ca-carbonates. On the other hand, contents in exchangeable $\mathrm{Mg}^{2+}, \mathrm{K}^{+}$and $\mathrm{Na}^{+}$have increased in all examined layers of the irrigated calcisol (Table 3). These increases are very significant in the upper soil layer and can be attributed to the relatively high concentrations of the Sfax TW in these cations (Table 2). In the deepest layer, the same intensifications may have been enhanced by the wastewater drainage through the ripping of the carbonate crust in the irrigated field. The examination of the electrical conductivity of the saturation paste soil extracts (ECs) approves that 15-year long irrigation period by the Sfax TW results in significant supply of ion into the calcisol (Table 4), even in the deepest layers. As a consequence, soil salinity was up to $4 \mathrm{mS} \cdot \mathrm{cm}^{-1}$ at all depths, and sometimes exceeded this level.

Analyses of the ammonium and nitrate concentrations in the soil water extracts and of the soil organic carbon also reveal the impact of the irrigation by the Sfax TW. In the irrigated soil, the contents in extractable $\mathrm{NH}_{4}{ }^{+}$remain low and never exceed $0.1 \mathrm{cmol}^{+} \cdot \mathrm{Kg}^{-1}$ in the dry soil (Table 3). However, as with the other base cations origin- nating from the applied wastewater, the $\mathrm{NH}_{4}^{+}$contents of the soil generally increase with depth and are significantly higher in the irrigated soil compared to the non irrigated one (Table 3). Similarly, significant contents in extractable nitrate are found in the deepest 60 $90 \mathrm{~cm}$ layer of the irrigated soil confirming drainage by the added TW (Table 3). Although much more variable than ammonia, the nitrate contents of the soil water extracts are also systematically higher in the irrigated soil than in the non-irrigated one. Soil organic carbon contents (SOC) follow similar trends with values decreasing with depth in the irrigated soil (Tables 3 and 4).

According to the isohumic natureof the studied calcisol, SOC contents are elevated reaching $0.8 \%$. Contents 
Table 3. Effects of TW irrigation on some chemical properties (significant differences between irrigated soil compared to control soil showing a $\mathrm{p}<0.01)$.

\begin{tabular}{|c|c|c|c|c|c|c|c|}
\hline & \multirow{2}{*}{ Depth (cm) } & \multirow{2}{*}{ Control value } & \multicolumn{3}{|c|}{ Values for irrigated sites } & \multicolumn{2}{|c|}{ One sample T-test } \\
\hline & & & $\mathbf{N}$ & Mean & SEM & $\mathbf{T}$ & $\mathbf{P}(\%)$ \\
\hline \multirow{2}{*}{$\mathbf{p H}_{\mathrm{w}}$} & $0-30$ & 8.54 & 7 & 8.28 & 0.0764 & -3.32 & 1.581 \\
\hline & $30-60$ & 8.85 & 7 & 8.65 & 0.0626 & -3.17 & 1.924 \\
\hline \multirow{2}{*}{ ECs $\mathbf{m S} \cdot \mathrm{cm}^{-1}$} & $0-30$ & 1.38 & 7 & 4.09 & 0.4608 & 5.89 & $0.053^{*}$ \\
\hline & $30-60$ & 0.87 & 7 & 4.35 & 0.4881 & 7.14 & $0.018^{*}$ \\
\hline \multirow{2}{*}{$\begin{array}{ll}\mathrm{NH}_{4}^{+} & \mathrm{cmol}^{+} / \mathrm{kg}\end{array}$} & $0-30$ & 0.02 & 7 & 0.07 & 0.0062 & 8.29 & $0.008^{*}$ \\
\hline & $30-60$ & 0.03 & 7 & 0.06 & 0.0058 & 5.98 & $0.048^{*}$ \\
\hline \multirow{2}{*}{$\mathrm{NO}_{3}^{-} \mathrm{cmol}^{-} / \mathrm{kg}$} & $0-30$ & 0.02 & 7 & 0.19 & 0.0276 & 6.26 & $0.038^{*}$ \\
\hline & $30-60$ & 0.00 & 7 & 0.09 & 0.0191 & 5.00 & $0.122^{*}$ \\
\hline \multirow{2}{*}{ SOC $\%$} & $0-30$ & 0.42 & 7 & 0.52 & 0.1388 & 1.23 & 26.311 \\
\hline & $30-60$ & 0.42 & 7 & 0.30 & 0.0772 & -2.68 & 3.638 \\
\hline \multirow{2}{*}{ DOC mg/kg } & $0-30$ & 17 & 7 & 43.92 & 1.6445 & 16.36 & $0.0003^{*}$ \\
\hline & $30-60$ & - & 7 & - & - & - & - \\
\hline \multirow[b]{2}{*}{$\mathrm{K}^{+} \mathrm{cmol}^{+} / \mathbf{k g}$} & $0-30$ & 5.00 & 7 & 10.25 & 1.0788 & 4.86 & $0.1403^{*}$ \\
\hline & $30-60$ & 3.94 & 7 & 9.74 & 1.0028 & 5.78 & $0.0583^{*}$ \\
\hline \multirow{2}{*}{$\mathrm{Na}^{+} \mathrm{cmol}^{+} / \mathbf{k g}$} & $0-30$ & 0.32 & 7 & 2.59 & 0.2347 & 9.69 & $0.0035^{*}$ \\
\hline & $30-60$ & 0.65 & 7 & 2.44 & 0.2643 & 6.78 & $0.0250^{*}$ \\
\hline \multirow{2}{*}{$\mathrm{Ca}^{2+} \mathrm{cmol}^{+} / \mathrm{kg}$} & $0-30$ & 39.62 & 7 & 40.96 & 2.0748 & 0.64 & 54.2487 \\
\hline & $30-60$ & 49.50 & 7 & 43.7 & 0.9096 & -6.32 & $0.0732^{*}$ \\
\hline \multirow{2}{*}{$\mathrm{Mg}^{2+} \mathrm{cmol}^{+} / \mathbf{k g}$} & $0-30$ & 1.00 & 7 & 6.44 & 0.2512 & 21.66 & $0.0000^{*}$ \\
\hline & $30-60$ & 1.32 & 7 & 5.63 & 0.1172 & 36.78 & $0.0000^{*}$ \\
\hline
\end{tabular}

N: Number of samples; T: Observed Student statistic $(\mathrm{T}=$ Mean-control/SEM); SEM: Mean standard error for measurements in irrigated field; $\mathrm{p} \%$ : Error risk " significant at $\mathrm{p}<1 \%$. SOC: Soil organic matter; DOC: Dissolved organic carbon; ECs: Electric conductivity of soil.

Table 4. Chemical properties of irrigated and not irrigated soil profile.

\begin{tabular}{|c|c|c|c|c|c|c|c|}
\hline Soil depth (cm) & $\mathbf{p H}_{\mathbf{w}}$ & $\mathbf{p H}_{\mathrm{KCl}}$ & $\mathrm{CEC}\left(\mathrm{cmol}^{+} / \mathbf{k g}\right)$ & S (\%) & Nt (\%) & $\operatorname{SOC}(\%)$ & $\mathbf{C} / \mathbf{N}$ \\
\hline \multicolumn{8}{|c|}{ Irrigated soil profile } \\
\hline H1 (0 - 10) & 8.54 & 7.79 & 10.01 & 83.29 & 0.0476 & 0.80 & 16.80 \\
\hline H2 (10 - 30) & 9.15 & 8.04 & 9.97 & 75.67 & 0.0049 & 0.44 & 88.77 \\
\hline \multicolumn{8}{|c|}{ Not irrigated soil profile } \\
\hline H1 (0 - 20) & 8.55 & 7.9 & 7.70 & 79.29 & 0.0028 & 0.15 & 53.57 \\
\hline H2 (20 - 35) & 8.85 & 7.78 & 10.15 & 76.55 & 0.0042 & 0.10 & 23.89 \\
\hline H3 (35 - 50) & 8.83 & 7.79 & 8.12 & 106.74 & 0.0245 & 0.25 & 10.20 \\
\hline
\end{tabular}

CEC: Cation exchange capacity; S: Saturation in exchangeable cations; Nt: Total nitrogen; SOC: Soil organic carbon. 
in organic carbon are not significantly higher in the irrigated soil than in the control one (Table 3). However, the same values around $0.4 \%$ are found in the two studied soil layers of the non irrigated calcisol while SOC contents are generally higher in the surface layer than in the deeper one in the irrigated soil. This indicates the supply of organic carbon by the irrigation by the treated wastewater.

The examination of the DOC, $\mathrm{C} / \mathrm{N}$ ratio and SUVA (Table 5) highlights the impact of the TW irrigation on soil organic matter quality (SOM). The $\mathrm{C} / \mathrm{N}$ ratio ranges between 20 and 36 in the irrigated calcisol whereas it remains around 70 in the control site. This indicates an acceleration of the SOM humification in the irrigated field compared to the non irrigated one. The DOC content of the soil water extract, which is related to the fraction of labile carbon, is three times higher in the irrigated calcisol than in the control. By the same way, the fraction of aromatic carbon as estimated by the SUVA ratio is more important in the calcisol that has been submitted to the wastewater irrigation for 15 years.

\subsection{Quantitative Supply in Macro and Micro Nutrients by the TW irrigation}

Isovolumic mass balance was calculated in order to quantify the supply of micro and macro nutrients by the 15-year-long TW irrigation. Organic carbon, total nitrogen and phosphourous, as well as essential cations pools were expressed in mass per unit of soil area (Table 6) using thickness and bulk density of each horizon of soil as employed by Keller and Védy [21]. The percentages of pool change were calculated between the two surficial horizons in reference to the equivalent thickness of the deepest horizon of soil by assuming a conservative element. It was thus assumed that the deepest horizon of soil has not been impacted by the treated wastewater (Table 4).
Similarly, the equivalent deep scope of reference was found by using Si and Ti as conservative elements: $31 \mathrm{~cm}$ and $40 \mathrm{~cm}$ for the irrigated and the control area respectively. A negative pool change reflects a loss of elements from the $\mathrm{H} 1-\mathrm{H} 2$ horizon to the $\mathrm{H} 3$ while a positive value reflects a gain. However, because of the risk of error accumulation, a $15 \%$ range of uncertainty has to be considered especially for micro nutrients $(\mathrm{Mn}, \mathrm{Cu}$, and $\mathrm{Zn}$ ). Results show no variation in the change of $\mathrm{K}, \mathrm{Fe}$ and $\mathrm{Cu}$ between the control and the irrigated pedons (Table 6). Conversely, significant differences appear for other essential elements. Compared to the control pedon, the irrigated pedon shows switch in $\mathrm{Ca}$ and $\mathrm{Na}$ due to the supply of sodium by the TW. Mn and $\mathrm{Zn}$ are less preserved in the irrigated soil profile. Concerning amounts of SOC, $\mathrm{P}$ and $\mathrm{N}$ (Table 6), results indicate that the irrigation by the Sfax TW has mitigated the loss in total nitrogen and increased the pool in organic carbon and in total phosphorus.

\section{DISCUSSION}

\subsection{Impact of Irrigation on the Soil Macro and Micro Nutrients}

The quality of the Sfax treated wastewater (TW) has varied since 1984. However, values of parameters indicating the salinity $(\mathrm{ECw}, \mathrm{Cl})$ and the sodicity $(\mathrm{SAR}, \mathrm{Na})$ remained largely superior to the limits established by the F.A.O. [4] for the reuse of wastewater in agricuture. Aside salts and sodium, the Sfax TW concentrations in dissolved organic carbon, $\mathrm{BDO}_{5}$ and suspended matter exceed the Tunisian standards for water reuse in irrigation (NT 106.03). Compared to other treated urban effluents from Sardinia, Tunisia and Jordan respectively $[6,11,22]$, the Sfax TW also provide higher concentrations in macro nutrients such as ammonia, nitrate, total phosphorus and

Table 5. Organic pattern of the TW and of the surface soil layers $(0-30 \mathrm{~cm})$ of irrigated and not irrigated soils.

\begin{tabular}{ccccccc}
\hline Samples & Nt (g/100g) & SOC (g/100g) & C/N & DOC (mg/kg) & Abs 254 & SUVA \\
\hline IWC1 & 0.018 & 0.53 & 29.4 & 43.1 & 0.80 & 1.86 \\
IWC2 & 0.021 & 0.77 & 36.6 & 45.6 & 0.94 & 2.07 \\
IWC3 & 0.017 & 0.34 & 20.0 & 38.8 & 0.60 & 1.54 \\
IWC4 & 0.018 & 0.35 & 19.5 & 40.0 & 0.62 & 1.55 \\
IWC5 & 0.035 & 0.81 & 23.0 & 43.8 & 0.78 & 1.80 \\
IWC6 & 0.019 & 0.59 & 31.3 & 52.1 & 0.86 & 1.65 \\
IWC7 & 0.014 & 0.28 & 20.0 & 44.1 & 0.71 & 1.62 \\
NIC & 0.006 & 0.42 & 70.5 & 17.0 & 0.17 & 1.02 \\
\hline
\end{tabular}

IWC: Irrigated Wastewater Calcisol; NIC = Control: Not Irrigated Calcisol; TN: Total Nitrogen; SOC: Organic Carbon; C/N: Soil C:N Ratios. DOC: Dissolved Organic Carbon; Abs 254: UV absorbance of soil water extract at 254 nm; SUVA: Specific UV Absorption = Abs 254/DOC. 
Table 6. Isovolumic masse balance of change between $\mathrm{H} 1-\mathrm{H} 2$ and $\mathrm{H} 3$ layers in the irrigated and not irrigated profiles.

\begin{tabular}{|c|c|c|c|c|c|c|c|c|c|c|c|}
\hline Soil depth (cm) & $\underset{\mathrm{kg} / \mathrm{m}^{2}}{\mathrm{Mg}}$ & $\underset{\mathrm{kg} / \mathrm{m}^{2}}{\mathrm{Ca}}$ & $\underset{\mathrm{kg} / \mathrm{m}^{2}}{\mathrm{Na}}$ & $\underset{\mathrm{kg} / \mathrm{m}^{2}}{\mathrm{~K}}$ & $\underset{\mathrm{kg} / \mathrm{m}^{2}}{\mathrm{Mn}}$ & $\underset{\mathrm{kg} / \mathrm{m}^{2}}{\mathrm{Fe}}$ & $\underset{\mathrm{kg} / \mathrm{m}^{2}}{\mathrm{Cu}}$ & $\underset{\mathrm{kg} / \mathrm{m}^{2}}{\mathrm{Zn}}$ & $\underset{\mathrm{kg} / \mathrm{m}^{2}}{\mathrm{SOC}}$ & $\underset{\mathrm{kg} / \mathrm{m}^{2}}{\mathrm{Nt}}$ & $\underset{\mathrm{kg} / \mathrm{m}^{2}}{\mathrm{P}}$ \\
\hline \multicolumn{12}{|c|}{ Irrigated soil profile } \\
\hline H1 (0 - 10) & 0.7 & 5.5 & 0.2 & 1.2 & 0.02 & 1.5 & 0.68 & 2.4 & 1.2 & 0.07 & 0.07 \\
\hline H2 (10 - 30) & 1.4 & 10.7 & 0.4 & 2.5 & 0.04 & 3.1 & 1.14 & 4.0 & 1.2 & 0.01 & 0.11 \\
\hline H3 (30 - 50) & 1.6 & 33.6 & 0.5 & 2.3 & 0.03 & 3.5 & 1.29 & 4.3 & 1.0 & 0.08 & 0.07 \\
\hline Change (\%) & -17 & -69 & -23 & $\mathbf{0}$ & 65 & -17 & -5 & -10 & 49 & -35 & 66 \\
\hline \multicolumn{12}{|c|}{ Not irrigated soil profile (control pedon) } \\
\hline H1 (0 - 20) & 1.0 & 6.9 & 0.3 & 2.1 & 0.05 & 2.5 & 0.96 & 5.0 & 0.4 & 0.01 & 0.05 \\
\hline H2 (20 - 35) & 1.1 & 9.3 & 0.3 & 2.0 & 0.04 & 2.9 & 1.06 & 3.4 & 0.2 & 0.01 & 0.04 \\
\hline H3 (35 - 50) & 0.9 & 11.1 & 0.2 & 1.7 & 0.03 & 2.5 & 0.86 & 2.7 & 0.5 & 0.05 & 0.04 \\
\hline Change (\%) & -16 & -45 & -6 & -8 & 106 & -17 & -12 & 17 & -50 & -86 & -15 \\
\hline
\end{tabular}

potassium (Table 2). Nevertheless, concentrations in nitrate, phosphorous and potassium are much lower in the Sfax TW than in untreated wastewater [5].

The quantitative mass balance results obtained in the irrigated and not irrigated fields (Table 6) shows the effects of the Sfax's TW properties. Indeed, the 15 yearlong irrigation period does not lead to change the pools in $\mathrm{Mg}, \mathrm{K}, \mathrm{Cu}$ and $\mathrm{Fe}$. Conversely, it has increased the pools of SOC $(+100 \%)$ and of total $\mathrm{P}(+80 \%)$ in the topsoil layer compared to the subsoil level. Likewise, the TW irrigation has led to preservation of $50 \%$ of the pool in total N. Consequently, concentrations of available mineral nitrogen $\left(\mathrm{NO}_{3}^{-}\right.$and $\mathrm{NH}_{4}^{+}$) have significantly been increased by the irrigation (Table 3). The nitrate and ammonium can either be directly brought by the wastewater or indirectly by the turnover of the organic matter and subsequent $\mathrm{N}$ mineralization.

In the case study, results suggest simultaneous increases in the organic pool (cf. Tables 5 and $\mathbf{6}$ either for SOC and total Nitrogen) and in the rate of organic matter turnover (cf. Table 4 for nitrate and ammonia and Table 5 for DOC) indicating enhancement of the $\mathrm{C}$ and $\mathrm{N}$ mineralisation. Such impacts have already been noticed in incubation experiments [23] for loamy Appalachian forest soils (Typic Hapludult) that have been irrigated with a municipal treated wastewater for two years. The used treated wastewater contained similar nitrate $\left(19.4 \mathrm{mg} \cdot \mathrm{L}^{-1}\right)$ and total $\mathrm{P}$ concentration $\left(3.15 \mathrm{mg} \cdot \mathrm{L}^{-1}\right)$ than in the Sfax's TW but much lower concentration in ammonia (1.73 $\left.\mathrm{mg} \cdot \mathrm{L}^{-1}\right)$. However, the enhancement of the $\mathrm{N}$ mineralization by TW irrigation is not systematic. Ramirez-Fuentes et al. [13] has not recorded any changes in the $\mathrm{N}$ turnover during the incubation of various Mexican types of soils irrigated with untreated wastewater. Magesan et al. [12] have even noticed a reduction of the amount of leached nitrate for soil irrigated with TW. As mentioned by Herpin et al. [7] TW impacts on the nutrients turnover are mostly influenced by the difference between the $\mathrm{C} / \mathrm{N}$ ratio of the soil and of the wastewater effluent.

In the studied case, the enhancement of the organic $\mathrm{C}$ and $\mathrm{N}$ mineralization can be explained by the quantitative variations in pools of micro nutrients. $\mathrm{Mn}$ and $\mathrm{Zn}$ are thus both known to be associated with soil organic matter. The rise of the SOM turnover has certainly intensified the availability of these micro nutrients turnover and facilitates their uptake by plants. Such kind of dependence between the turnover of soil organic matter and $\mathrm{Zn}$ translocation to the aerial parts has already been observed in other soil types (Andic soil) [24]. As opposed to the irrigated field, the control area is not used for annual crops production. The cultural differences between the irrigated and the non-irrigated field thus make it difficult to interpret data because the sum of essential nutrients uptaken by plant is certainly much lower in the control area than in the irrigated field.

\subsection{Impacts of Irrigation on the Soil Organic Matter Quality}

Several parameters have to be considered altogether in order to understand the impact of the TW irrigation on the quality of the soil organic matter (Table 5): $\mathrm{C} / \mathrm{N}$ ratio, total content of dissolved organic carbon (DOC) and specific UV absorption ration (SUVA).

In the irrigated topsoil layer $(0-30 \mathrm{~cm})$, the soil $\mathrm{C} / \mathrm{N}$ ratio is low compared to those of non-irrigated soil, implying an enhancement of the SOM biodegradability. This is confirmed by the amount of DOC extracted from the irrigated soil samples. The SUVA was originally designed for estimating amounts of aromatic $\mathrm{C}$ in DOC fraction in waters $[25,26]$. It has been successfully used 
to compare these overall quantities in humic substances of waters as well [27]. The latter aromatic $\mathrm{C}$ fraction can be sought for assessing water contamination by halogenorganic compounds [28]. In soil, aromatic $\mathrm{C}$ fraction is considered as being more stable than the labile DOC soil fraction made of proteins or carbohydrates [29]. Thus, a high SUVA value of the soil DOC fraction reveals a more important consumption of the labile $\mathrm{C}$ fraction by the soil microbial communities [30]. This not only indicates a higher degree of degradation of the labile organic matter, but also a change in the SOC quality. Korshin et al. [31] stated that the absorbance at $254 \mathrm{~nm}$ is even increased by the presence of polar functions in aromatic compounds, such as by hydroxyls, carbonyls, carboxylic and ester functions. An elevated SUVA ratio can therefore also outlines the SOM reactivity or its ability to form combinations with the soil mineral fraction.

As mentioned in the previous studies, the input of available micro nutrients and labile fraction of organic $\mathrm{C}$ by TW irrigation can over stimulate the microbial activity of the soil $[12,13]$. In adequate soil conditions, this results in an enhancement of the $\mathrm{C}$ mineralization rate, with subsequent decrease of the total SOC content in less than 4 years of TW [7]. Yet, inconsistent results are found over the long term. In Mexican Leptic calcaric soil [10], the irrigation for 50 years with untreated wastewater has depleted the SOC content in rate of $53 \%$ whereas in India (various soil types of $\mathrm{pH}_{\mathrm{w}}$ ranging between 5.1 to 9.9), Rattan et al. [8] recorded an increase of the SOC content in rate of $59 \%$ after 20 years of irrigation with untreated effluents.

In the case study, the combination of values of $\mathrm{C} / \mathrm{N}$ ratio, DOC, SUVA and SOC contents clearly reveals an enhancement of the organic material turnover in the irrigated soil compared to the non irrigated one. However, despite the DOC supply in large amounts by the Sfax's TW (Table 2), the irrigation of the studied calcisol has not systematically implied changes in the total content of soil organic carbon (SOC), compared to the non irrigated soil (Table 3). Huge variability of SOC contents are indeed noticed in the topsoil layer of the irrigated field, so that the mean values are not statstically different from the reference value of the non irrigated field (Table 3). This result suggests the influence of contradictory processes to the organic matter mineralization.

It has to be noticed that the Sfax's TW are particularly rich in salt and sodium. Chow et al. [25] have perceived that the soil salinisation and sodification affects the SOM structure as to decrease the DOC content in the leaching soil waters. As shown in Figure 2, a significant negative correlation is indeed found between the soil ECs and the DOC in the irrigated soil $(\mathrm{R}=-0.63, \mathrm{p}<0.05)$. Romkens and Dolfing [32] explained that free $\mathrm{Ca}^{2+}$ cations exchanged by the added $\mathrm{Na}^{+}$flocculate more than $50 \%$ of

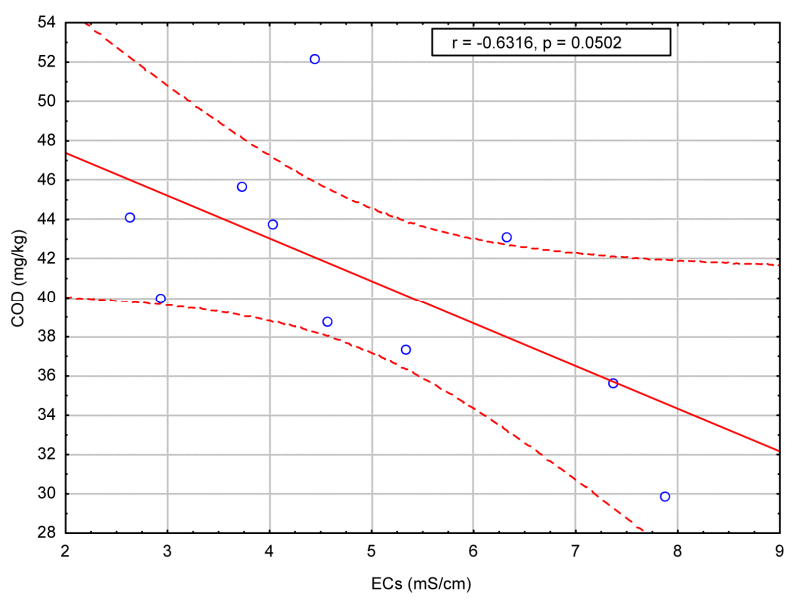

Figure 2. The correlation between dissolved organic carbon (DOC) in the water soil extracts and electric conductivity (ECs) of the surface layers of irrigated soils.

the soil DOC. Rietz and Haynes [33] added that the increase of the soil salinity leads to an inhibition of the soil microbial activity, and thus to significant decrease of the SOM mineralization. Likewise, the latter contents stabilization takes place in the studied calcisol corresponding to its mineralization enhancement by means of TW' application. Subsequently, this procedure tends to explain the variability of resulting contents of SOC in the irrigated field (Table 5). Over the long term, salt-inducing SOM stabilization can also lead to a decrease of crop yields [33].

\subsection{The Risk of Fertility Loss over the Long Term}

Over the long term, salt-inducing SOM stabilization can lead to decrease of crop yields [33]. The relationship between salinity of irrigated soils (ECs) and their content in labile carbon (DOC) thus gives an insight of further risks of soil losses of the studied calcisol fertility afterwards (Figure 2). The relationships between nitrate, ammonium contents and the evolution of the quality of the soil organic matter (as seen by the C/N ratio, SUVA and DOC contents in soil water extracts) suggest long term risk of degradation of groundwater quality by the leaching waters.

The irrigation clearly leads to a decrease of the contents in nitrate and ammonium in the water extracts of soils, not only at the soil surface, but also in the deepest soil layer (see Table 3 and [15]). DOC of the applied effluent, as well as the soil DOC fraction only represent small parts $(0.01 \%$ up to $0.1 \%)$ of the total SOM in soils. It is also the more mobile and the further used $\mathrm{C}$ fraction for heterotrophic microbial communities involved in the $\mathrm{N}$ turnover. Kim and Burger, [23] showed that nitrogen supply by treated effluents favored nitrification and 
leaching of nitrate because the amounts of available nitrogen, supplied by the TW, largely exceed the plant demand. As seen in Tables 4 and $\mathbf{6}$, the control calcisol is naturally poor of nitrogen. The presence of active carbonates in this type of soil also usually causes natural inhibition of microbial activity, which is indicated in this present case by a $\mathrm{C} / \mathrm{N}$ ratio above 70 . Moreover, the CEC of the studied calcisol remains low compared to other equivalent to calcareous soils in which $\mathrm{CEC}$ reach values up to $20 \mathrm{cmol}^{+} \cdot \mathrm{Kg}^{-1}[15,34]$. Due to the low CEC and to the elevated irrigation rate, ammonia cations supplied by the Sfax TW have limited chances of being absorbed by the soil. In such context, nitrate and ammonium contents occurring in the deepest layer are certainly deriving straight from the applied wastewater. The two mineral nitrogen ions are leached down to the root zone and risk to reduce the upper soil layer fertility. As a matter of fact, this can also cause degradation of the soil leaching water and consequently of the free groundwater below roots and transient zones. Apart from risks of degradation of groundwater quality, there are also concerns for the condition of the crop harvest. Indeed the excess of available mineral nitrogen in soil usually lead to the breaking of forage crops during the maturation stage (oat and soghum).

The previous studies have also identified losses in essential nutrients $(\mathrm{Ca}, \mathrm{Mg}, \mathrm{K}, \mathrm{Na}, \mathrm{Cu}, \mathrm{Zn}, \mathrm{Mn})$ and soil acidification as others risks of degradation of the fertility of alkaline calcareous soils being irrigated by domestic effluents for several decades $[5,8,10,11]$. In the studied case, the 15 -year long wastewater irrigation has not affected the $\mathrm{pH}$ of the soil. This result can be explained by an important buffer capacity of the examined calcisol. Calcium represents the most abundant exchangeable base cation (Table 3). As seen along the two pedological pits, horizons of soil are nearly saturated in essential base cations (Table 4). Belaïd et al. [15] already mentioned significant linear correlations $(p<0.05)$ between the $\mathrm{CEC}$ and the contents of exchangeable cations added by the TW: $\mathrm{Na}^{+}(\mathrm{R}=0.94), \mathrm{K}^{+}(\mathrm{R}=0.79)$ and $\mathrm{Mg}^{2+}(\mathrm{R}=$ 0.99 ). The quantitative analysis of pool changes for $\mathrm{Ca}$ and $\mathrm{Na}$ in the irrigated pedon validates the exchanges of natural $\mathrm{Ca}^{2+}$ by the supplied $\mathrm{Na}^{+}$(Table 5). Exchangeable contents in $\mathrm{Mg}^{2+}, \mathrm{K}^{+}$and $\mathrm{Na}^{+}$, have generally increased only in the irrigated soil (Table 3). These cations developments are corresponding with its relatively high concentrations in the treated wastewater used for irrigation. Although total amounts in these essential cations have not significantly changed at the scale of the soil profile (Table 5), there is a risk over the long term of loss of these elements due to the high rate of irrigation and low soil CEC (Table 4). On the other hand, due to the salinity of the Sfax's TW, important amounts of the supplied Na are leached down to the deepest horizon of soil in the irrigated field initiating sodification of groundwater.

\section{CONCLUSION}

The Sfax treated wastewater (TW) is particularly rich in available organic carbon and mineral nitrogen. Irrigation for 15 years with the Sfax TW has not significantly changed the $\mathrm{pH}$ of the studied calcisol and the SOC content of the topsoil layer. The results of the present study also confirm, under field conditions, processes previously identified in laboratory experiments about the impact of wastewater effluents on the quality of the soil organic matter. From a quantitative respect, the 15 -yearlong irrigation by the Sfax TW has limited the loss of micro nutrients such as $\mathrm{Mn}$ and $\mathrm{Zn}$. It has also supplied important amounts in most essential macro nutrients ( $P$ and $\mathrm{N}$ ). The irrigation by the TW has also clearly enhanced the $\mathrm{C}$ and $\mathrm{N}$ turnover in the studied calcisol which fertility was naturally limited by the elevated content in active carbonates. If these beneficial effects could reduce the cost of mineral fertilization and aid the production of crops, the continuous use of the TW arises some questions concerning soil fertility and groundwater protection over the long term. In the case study, because of the elevated concentrations in sodium and salts of the applied TW, the beneficial activation of the microbial activity and the resulting availability of essential elements could be quickly inhibited. Moreover, due to the elevated irrigation rate and the low CEC of the soil, the TW irrigation has clearly increased the leaching of mineral nutrients such as nitrate and exchangeable $\mathrm{K}, \mathrm{Mg}$, and Na. Further irrigation, even with natural water, could stand for an imminent threat for the quality of the free watertable in the Sfax region by increasing concentrations in nitrate, sodium and salt. Apart from this problem, the excessive supply of salts and available nitrogen already constitutes a risk for the future crops production. However, since these speculations only concerned one calcisol filed, the validity of our conclusions need to be verified across a wider study area and for the other types of soils that were irrigated with the Sfax TW.

\section{ACKNOWLEDGEMENTS}

The authors gratefully acknowledge the staff of the CRDA-Sfax for their cooperation during site selection and soils sampling.

\section{REFERENCES}

[1] Bahri, A. (1987) Utilization of treated wastewater and sewage sludge in agriculture in Tunisia. Desalination, 67, 233-244.

[2] Bahri, A. (2002) Water reuse in Tunisia: Stakes and prospects. Actes de l'atelier du PCSI, Montpellier, 1-11. 
[3] Haruvy, N. (1997) Agricultural reuse of wastewater: Nation-wide cost-benefit analysis. Agriculture Ecosystem Environment, 66, 113-119. doi: 10.1016/S0167-8809(97)00046-7

[4] Pescod, M.B. (1992) Wastewater treatment and use in agriculture. Bulletin FAO 47, Rome, 125.

[5] Yadav, B., Goyal, R.K., Sharma, S.K., Dubey, P.S. and Minhas, R.K. (2002) Post-irrigation impact of domestic sewage effluent on composition of soils, crops and groundwater-A case study. Environment International, 28, 481486. doi:10.1016/S0160-4120(02)00070-3

[6] Coppola, A., Santini, A., Botti, P., Vacca, S., Comegna, V. and Severino, G. (2004) Methodological approach for evaluating the response of soil hydrological behavior to irrigation with treated municipal wastewater. Journal of $\mathrm{Hy}$ drology, 292, 114-134.

doi:10.1016/j.jhydrol.2003.12.028

[7] Herpin, U., Gloaguen, T.V., da Fonseca, A.F., Montes, C.R., Mendonça, F.C., Piveli, R.P., Breulmann, G., Forti, M.C. and Et Melfi, A.J. (2007) Chemical effects on the soil-plant system in a secondary treated wastewater irrigated coffee plantationcA pilot field study in Brazil. Agriculture Water Management, 89, 105-115. doi:10.1016/j.agwat.2007.01.001

[8] Rattan, R.K., Datta, S.P., Chhonkar, P.K., Suribabu, K. and Singh, A.K. (2005) Long-term impact of irrigation with sewage effluents on heavy metal content in soils, crops and groundwater-A case study. Agriculture Ecosystem and Environment, 109, 310-322. doi:10.1016/j.agee.2005.02.025

[9] Abbas, S.T., Sarfraz, M., Mehdi, S.M., Hassan, G. and Rehman, O.U. (2007) Trace elements accumulation in soil and rice plants irrigated with the contaminated water. Soil \& Tillage Research, 94, 503-509. doi:10.1016/i.still.2006.10.004

[10] Solis, C., Andrade, E., Mireles, A., Reyes-Solis, I.E., Garcia-Calderon, N., Lagunas-Solar, M.C., Pina, R.G. and Flocchini, C.U. (2005) Distribution of heavy metals in plants cultivated with wastewater irrigated soils during different periods of time. Nuclear Instruments and Methods in Physics Research Section B, 241, 351-355. doi:10.1016/j.nimb.2005.07.040

[11] Rusan, M.J.M., Hinnawi, S. and Rousan, L. (2007) Long term effect of wastewater irrigation of forage crops on soil and plant quality parameters. Desalination, 215, 143152. doi:10.1016/j.desal.2006.10.032

[12] Magesan, G.N., Williamson, J.C., Yeates, G.W. and LoydJones, A.R. (2000) Wastewater C:N ratio effects on soil hydraulic conductivity and potential mechanisms for recovery. Bioresource Technology, 71, 21-27. doi:10.1016/S0960-8524(99)00054-1

[13] Ramirez-Fuentes, E., Lucho-Constantino, C., EscamillaSilva, E. and Dendooven, L. (2002) Characteristics, and carbon and nitrogen dynamics in soil irrigated with wastewater for different lengths of time. Bioresource Techology, 85, 179-187. doi:10.1016/S0960-8524(02)00035-4

[14] Bouri, S., Abida, H. and Khanfir, H. (2008) Impacts of wastewater irrigation in arid and semi arid regions: Case of Sidi Abid region, Tunisia. Environmental Geology, 53, 1421-1432. doi:10.1007/s00254-007-0751-5
[15] Belaid, N., Neel, C., Kallel, M., Ayoub, T., Ayadi, A. and Baudu, M. (2010) Effects of treated wastewater irrigation on salinity and sodicity of soils: A case study in Sfax (Tunisia). Journal of Water Science, 23, 133-145.

[16] FAO (1998) World Reference Base for Soil Resources, by ISSS-ISRIC-FAO. World Soil Resources Report No. 84. Rome, 88 p.

[17] AFNOR, et al. (1997) Water quality, analysis methodes. 3, 296.

[18] Orsini, L. and Remy, J.C. (1976) Utilisation du chlorure de cobaltihexamine pour la détermination simultanée de la capacité d'échange et des bases échangeables des sols. Sciences du sol, bulletin de l'AFES 4, 269-279.

[19] Metson, A.J. (1956) Methods of chemical analysis for soil survey samples. New Zealand Soil Bureau, 12.

[20] Baker, M.A., Valett, H.M. and Dahm, C.N. (2000) Organic carbon supply and metabolism in a shallow groundwater ecosystem. Ecology, 81, 3111-3148. doi:10.1890/0012-9658(2000)081[3133:OCSAMI]2.0.C $\underline{\mathrm{O} ; 2}$

[21] Keller, C. and Védy, J.-C. (1994) Distribution of copper and cadmium fractions in two forest soils. Journal of Environmental Quality, 23, 987-999. doi:10.2134/jeq1994.00472425002300050020x

[22] Klay, S., Charef, A., Ayed, L., Houman, B. and Rezgui, F. (2010) Effect of irrigation with treated wastewater on geochemical properties (saltiness, $\mathrm{C}, \mathrm{N}$ and heavy metals) of isohumic soils (Zaouit Sousse perimeter, Oriental Tunisia). Desalination, 253, 180-187. doi:10.1016/j.desal.2009.10.019

[23] Kim, D.Y. and Burger, J.A. (1997) Nitrogen transformations and soil processes in a wastewater-irrigated, mature Appalachian hardwood forest. Forest Ecology and Management, 90, 1-11. doi:10.1016/S0378-1127(96)03889-3

[24] Néel, C., Soubrand-Colin, M., Piquet-Pissaloux, A. and Bril, H. (2007) Mobility and availability of $\mathrm{Cr}, \mathrm{Ni}, \mathrm{Cu}, \mathrm{Zn}$ and $\mathrm{Pb}$ in a basaltic grassland: Comparison of selective extractions with quantitative approaches at different scales. Applied Geochemistry, 22, 724-735.

[25] Chow, A.T., Tanji, K.K. and Gao, S. (2003) Production of dissolved organic carbon (DOC) and trihalomethane (THM) precursor from peat soils. Water Research, 37, 4475-4485. doi:10.1016/S0043-1354(03)00437-8

[26] Xue, S., Zhao, Q.L., Wei, L.L., Wang, L.N. and Liu, Z.G. (2007) Fate of secondary effluent dissolved organic matter during soil-aquifer treatment. Chinese Science Bulletin, 52, 2496-2505. doi:10.1007/s11434-007-0339-1

[27] Traina, S.J., Novak, J. and Smeck, N.E. (1990) An ultraviolet absorbance method of estimating the percent aromatic carbon content of humic acids. Journal of Environmental Quality, 19, 151-153. doi:10.2134/jeq1990.00472425001900010023x

[28] Hassouna, M., Theraulaz, F., Lafolie, F. and Massiani, C. (2005) Characterisation and quantitative estimation of the hydrophobic, transphilic and hydrophilic fractions of DOC in soil using direct UV spectroscopy. Geophysical Research Abstracts, 7, 3 p.

[29] Kalbitz, K., Schmerwitz, J., Schwesig, D. and Matzner, E. 
(2003) Biodegradation of soil-derived dissolved organic matter as related to its properties. Geoderma, 113, 273-291. doi:10.1016/S0016-7061(02)00365-8

[30] Van Miegroet, H., Boettinger, J.L., Baker, M.A., Nielsen, J., Evans, D. and Stum, A. (2005) Soil carbon distribution and quality in a montane rangeland-forest mosaic in northern Utah. Forest Ecology Management, 220, 284-299. doi:10.1016/j.foreco.2005.08.017

[31] Korshin, G.V., Li, C.W. and Benjamin, M.M. (1997) Monitoring the properties of natural organic matter through UV spectroscopy: A consistent theory. Water Research, 31, 1787-1795. doi:10.1016/S0043-1354(97)00006-7

[32] Romkens Paul, F.A.M. and Dolfing, J. (1998) Effect of
$\mathrm{Ca}$ on the solubility and molecular size distribution of $\mathrm{DOC}$ and $\mathrm{Cu}$ binding in soil solution samples. Environmental Science and Technology, 32, 363-369. doi:10.1021/es970437f

[33] Rietz, D.N. and Haynes, R.J. (2003) Effects of irrigation-induced salinity and sodicity on soil microbial activity. Soil Biology and Biochemistry, 35, 845-854. doi:10.1016/S0038-0717(03)00125-1

[34] Jalali, M., Merikhpour, H., Kaledhonkar, M.J. and Van Der Zee, S.E.A.T.M. (2008) Effects of wastewater irrigation on soil sodicity and nutrient leaching in calcareous soils. Agricultural Water Management, 95, 143-153. doi:10.1016/j.agwat.2007.09.010 